\title{
Psychological Distress during COVID-19 Curfews and Social Distancing in Saudi Arabia: A Cross- Sectional Study
}

Badrah S Alghamdi ( $\sim$ basalghamdi@kau.edu.sa )

King Abdulaziz University https://orcid.org/0000-0002-9411-3609

Yasser AlAtawi

University of Tabouk

Fahad S. AlShehri

Umm Al-Qura University

Haythum 0. Tayeb

King Abdulaziz University

Hanin Abo Abo Taleb

King Abdulaziz University

Amal Binsalman

King Abdulaziz University

Research article

Keywords: Mental health, COVID-19, Healthcare workers, Saudi Arabia

Posted Date: July 14th, 2020

DOI: https://doi.org/10.21203/rs.3.rs-40296/v1

License: () (1) This work is licensed under a Creative Commons Attribution 4.0 International License.

Read Full License

Version of Record: A version of this preprint was published at Frontiers in Public Health on January 4th, 2022. See the published version at https://doi.org/10.3389/fpubh.2021.792533. 


\section{Abstract \\ Background}

Coronavirus disease 2019 (COVID-19) has spread to over 150 countries worldwide. Since the first case of COVID-19 was confirmed in Saudi Arabia, cases have continued to escalate exponentially. The COVID-19 outbreak has had a negative effect on mental health and well-being. The study aim was to investigate the effects of the strict national regulations associated with the COVID-19 pandemic on the population's mental health.

\section{Methods}

This was a cross-sectional study of a convenience sample of Saudi residents. Participants completed an online questionnaire after 1 month of a nationwide 24-hour curfew. We measured psychological distress using the Depression, Anxiety and Stress Scale-21 (DASS-21). We ran binary logistic regression analyses to detect variables that significantly predicted DASS-21 scores.

\section{Results}

The sample comprised 2252 Saudi residents. The DASS-21 score means and standard deviations for depression and anxiety for the whole sample (10.73 \pm 10.29 and $6.98 \pm 8.30$, respectively) were in the range of mild depression and anxiety. In contrast, the mean DASS-21 stress score was within the normal range $(11.97 \pm 10.80)$. The mean stress score for healthcare workers was within normal range $(13.70 \pm$ $10.68)$, but was significantly higher than the mean score for the public $(11.56 \pm 10.89 ; P=.0006)$. Several variables (e.g. age, gender and history of contact with confirmed COVID-19 cases) were significantly associated with higher DASS-21 scores.

\section{Conclusions}

The COVID-19 pandemic has created a psychological burden. Therefore, there is an urgent need to implement emergency psychological interventions to reduce the negative psychosocial effects of the pandemic on public mental health.

\section{Background}

Coronavirus disease 2019 (COVID-19), caused by severe acute respiratory distress syndrome coronavirus 2 (SARS-CoV-2), has developed into a worldwide pandemic since December 2019 (Ou et al., 2020). As of May 2020, over 4.7 million people have been infected worldwide and there have been more than 300,000 deaths (Saudi Ministry of Health, 2020; WHO, 2020). The pandemic has had substantial global health, social and economic effects and resulted in large-scale enforcement of curfew regulations (Anderson et 
al., 2020; Ebrahim et al., 2020). Pandemics are associated with a major mental health burden (Cullen et al., 2020; Holmes et al., 2020; Perrin et al., 2009; Pfefferbaum and North, 2020). Studies demonstrating the mental health impact of COVID-19 have accumulated over recent months. Chinese studies have shown that approximately $35-50 \%$ of people have experienced psychological distress owing to the COVID-19 pandemic (Qiu et al., 2020; Wang et al., 2020a). High rates of psychological distress have also been reported in Australia (Newby et al., 2020), Italy (Rossi et al., 2020a; Rossi et al., 2020b), Mexico (Garcia-Priego et al., 2020), the UK (Jia et al., 2020), Singapore (Chew et al., 2020; Tan et al., 2020), France (Chaix et al., 2020), Germany (Jung et al., 2020), Portugal (Moreira et al., 2020), Brazil (Filgueiras and Stults-Kolehmainen, 2020), Japan (Ueda et al., 2020), India (Chew et al., 2020; Suryadevara et al., 2020), Nepal (Sigdel et al., 2020) and Iran (Vahedian-Azimi et al., 2020). The mental health burden includes stress, anxiety, depression, post-traumatic stress disorder (PTSD) and insomnia. Several of the above studies indicate that younger age, pre-existing mental health difficulties and the presence of chronic conditions are risk factors of psychological morbidity during pandemics. Because many variables may predispose individuals to psychological distress during pandemics, an increase in health-related anxiety is expected during these periods (Hall et al., 2008; Rubin et al., 2010). Disruption to daily economic and social activities as a result of social distancing practices and government lockdown regulations is also associated with substantial distress during pandemics (Van Bortel et al., 2016). The relationship between the aggressiveness of government lockdown regulations and anxiety has not been sufficiently studied. However, it is likely that the effects of such regulations on mental health may vary depending on the sociodemographic and psychosocial characteristics of the population being studied.

The Kingdom of Saudi Arabia (KSA) provides a model for a systematic, aggressive, nationwide plan to combat pandemics. The government dealt with the COVID-19 pandemic decisively and swiftly. COVID-19 reached the KSA on 2 March 2020, when the first cases were recorded. By 9 March, schools were closed, government services scaled down and travel restrictions imposed. A full curfew was first imposed on some cities on 23 March and was then enforced nationwide on 6 April. Public prayers in mosques were suspended. In 2012, the KSA experienced an outbreak of another coronavirus, the Middle East respiratory syndrome coronavirus (MERS-CoV), which may have primed the country and increased the responsiveness of the authorities (Zaki et al., 2012). The potential mental health burden related to COVID19 in the KSA has not been fully quantified. Although strict restrictions on social and economic activities and travel may cause heightened psychological distress, trust in the authorities' efforts and the potential success of these efforts may mitigate the risk of an increased psychological burden. Mental health data from the Saudi setting could provide helpful insights into the determinants of psychological health during pandemics and contribute to comparative studies across countries. Therefore, in this observational crosssectional study, we aimed to measure the levels of stress, anxiety and depression experienced by a sample of the public during the strict regulations associated with the COVID-19 pandemic regulations in the KSA.

\section{Methods}

Design and sample 
This study was approved by the research ethics committee of King Abdulaziz University (approval no. $234-20$ ). We recruited a convenience sample of Saudi public citizens and residents older than 18 years. Web-based digital data collection has been endorsed as an effective way to gain insights into the physical and psychological well-being of individuals during pandemics (Zhang et al., 2014). Therefore, given the travel restrictions and enforcement of social distancing, the sample was recruited from the Internet by distributing the study questionnaire on social media platforms and institutional email services. The questionnaire was prepared using one of the author's institutional accounts in Google Forms, a secure online data collection survey tool that allows participants to answer questions conveniently and anonymously. The questionnaire was distributed on 6 May 2020, after a month of a nationwide 24-hour curfew (Fig. 1). Data collection continued for a week, at which point the target sample size was reached.

\section{Sociodemographic and DASS-21 questionnaire}

We constructed a simple, self-report questionnaire for this study. The survey was disseminated in both English and Arabic to facilitate the participation of individuals skilled in both languages. The survey consisted of two sections. The first section contained questions about sociodemographic variables (age, education, marital status, employment status, income, nationality and Saudi region of residence). We also asked if participants had been diagnosed with COVID-19, if they were healthcare workers and if they had been in contact with a person who had COVID-19. In addition, we inquired whether participants worked as security personnel (e.g. police), as these individuals are responsible for carrying out and monitoring curfew policies in the streets and may therefore be subjected to unique levels of stress.

The second section of the questionnaire contained the Depression, Anxiety and Stress Scale-21 (DASS21) (Henry and Crawford, 2005; Lovibond, 2004). The DASS-21 is a simple and validated tool to assess psychological distress both in the clinical setting and the community (Lovibond, 1998; Norton, 2007). It consists of 21 questions, seven questions for each of the three target mental health phenomena (depression, anxiety and stress). The scale provides a cutoff value for each subscale. Participants who score above these cutoff values are considered to show mild, moderate, severe or extremely severe symptoms (Lovibond and Lovibond, 1996). The total DASS-21 score is also meaningful and denotes the presence of substantial psychological distress. Previous studies have demonstrated the validity of the DASS-21 compared with clinical psychiatric interviews in screening for depression, anxiety and stress with reasonable sensitivity and specificity (Beaufort et al., 2017; Tran et al., 2013). The Arabic version of the DASS-21 has been used in published studies (Alzahrani et al., 2019; Basudan et al., 2017; Kulsoom and Afsar, 2015). The DASS-21 has recently shown meaningful results in several studies in other countries assessing mental health in the context of the COVID-19 pandemic (Suryadevara et al., 2020; Vahedian-Azimi et al., 2020; Wang et al., 2020b).

\section{Statistical analysis}

We used frequencies, percentages, means and standard deviations for descriptive statistics. We calculated the total and subscale DASS-21 scores and subsequently calculated the means and standard 
deviations of those scores. We used a one-way analysis of variance test and chi-square to search for differences in DASS-21 subscale scores (depression, anxiety and stress) between participant subgroups of interest (the public, healthcare workers, security personnel), given that healthcare and security personnel may theoretically be subjected to more stress regarding COVID-19. Subsequently, we performed binary logistic regression analysis to identify risk factors for psychological distress and determine their role in the variability of the DASS-21 scores. The binary outcomes were coded as 'abnormal' for DASS-21 subscores above the established clinical thresholds and as 'normal' for scores below those thresholds. We calculated the odds ratios $(\mathrm{OR})$ and $95 \%$ confidence intervals $(\mathrm{Cl})$ based on the probability of having abnormal DASS-21 subscores. We set the threshold for statistical significance at $P<.05$. We performed statistical analysis using SAS, University Edition.

\section{Results}

We collected a total of 2334 survey responses. We excluded 64 responses from participants younger than 18 years. Another 18 responses were excluded owing to a discrepancy in the response data. We then analysed data for the remaining 2252 responses. The sociodemographic characteristics of all groups are presented in Table 1. Most participants were female (65\%). Most $(60 \%)$ were $\leq 38$ years; only slightly more than $8 \%$ were $\geq 59$ years. Nearly $80 \%$ of the sample had a Bachelor's degree or higher. A fifth of our participants were unemployed. Most participants (64\%) resided in the western region of the KSA. Only $10 \%$ were non-Saudi. Healthcare workers and security force personnel represented (19\%) and (4.8\%) of the total sample, respectively. Only $2 \%$ of the sample had been diagnosed with COVID- 19 .

The means and standard deviations of the depression and anxiety DASS-21 scores for the whole sample (10.73 \pm 10.29 and $6.98 \pm 8.30$, respectively) were in the range of mild depression and anxiety. In contrast, the means and standard deviations of the DASS-21 stress score were within the normal range (11.97 \pm 10.80). The mean stress score was within normal range for healthcare workers $(13.70 \pm 10.68)$, but was higher than the mean score of the public $(11.56 \pm 10.89 ; P=.0006)$ (Fig. 2). There were otherwise no significant differences between DASS-21 scores of the public, healthcare workers and security force personnel.

Figure 3 shows the proportions of participants experiencing different levels of psychological distress as defined by the DASS-21. At least one-third of the population experienced one form of psychological distress. The proportion of healthcare workers who reported stress was significantly higher than that of the public or security personnel $(P=.0004)$. There were otherwise no differences in the proportions of participants with depression or anxiety between the public, healthcare workers and security personnel ( $P$ $=.2109, P=.5662$, respectively).

Using binary logistic regression analysis, we investigated the potential contribution of the independent sociodemographic variables of interest to the DASS-21 subscores (Fig. 4). Women were more likely to have depression $(\mathrm{OR}=1.34,95 \% \mathrm{Cl}=1.10-1.63, P=.0039)$ and stress $(\mathrm{OR}=1.40,95 \% \mathrm{Cl}=1.14-1.72, P$ $=.0015)$ than males. Additionally, participants aged $\leq 48$ years were more likely to experience abnormal 
levels of depression, anxiety and stress compared with participants aged $\geq 59$ years $(P \otimes .05)$.

Furthermore, significantly lower levels of depression ( $\mathrm{OR}=.43,95 \% \mathrm{Cl}=.27-.68, P=.0003)$, anxiety (OR

$=.46,95 \% \mathrm{Cl}=.29-.75, P=.0017)$ and stress $(\mathrm{OR}=.48,95 \% \mathrm{Cl}=.29-.78, P=.0033)$ were found in participants living in northern regions of the country compared with participants living in middle regions.

The public was less likely to have abnormal levels of stress (OR $=.64,95 \% \mathrm{Cl}=.48-.85, P=.0024)$ compared with healthcare workers. Education level, employment status, marital status, income and nationality had no significant association with any DASS-21 subscores.

\section{Table-1}

Sociodemographic characteristics of the study sample. 


\begin{tabular}{|c|c|c|c|c|}
\hline \multirow[t]{2}{*}{ Variable } & $\begin{array}{l}\text { Total } \\
\text { sample }\end{array}$ & Public & $\begin{array}{l}\text { Healthcare } \\
\text { workers }\end{array}$ & $\begin{array}{l}\text { Security } \\
\text { forces }\end{array}$ \\
\hline & $\mathbf{N}(\%)$ & $\mathbf{N}(\%)$ & $N(\%)$ & $\mathbf{N}(\%)$ \\
\hline \multicolumn{5}{|l|}{ Age (years) } \\
\hline $18-28$ & $\begin{array}{l}797 \\
(35.39)\end{array}$ & $\begin{array}{l}597 \\
(35.01)\end{array}$ & 173 (39.59) & $\begin{array}{l}27 \\
(24.55)\end{array}$ \\
\hline $29-38$ & $\begin{array}{l}551 \\
(24.47)\end{array}$ & $\begin{array}{l}377 \\
(22.11)\end{array}$ & $116(26.54)$ & $\begin{array}{l}58 \\
(52.73)\end{array}$ \\
\hline $39-48$ & $\begin{array}{l}402 \\
(17.85)\end{array}$ & $\begin{array}{l}327 \\
(19.18)\end{array}$ & $63(14.42)$ & $\begin{array}{l}12 \\
(10.91)\end{array}$ \\
\hline $49-58$ & $\begin{array}{l}311 \\
(13.81)\end{array}$ & $\begin{array}{l}246 \\
(14.43)\end{array}$ & $54(12.36)$ & $\begin{array}{l}11 \\
(10.00)\end{array}$ \\
\hline$\geq 59$ & $\begin{array}{l}191 \\
(8.48)\end{array}$ & $\begin{array}{l}158 \\
(9.26)\end{array}$ & $31(7.09)$ & $2(1.82)$ \\
\hline \multicolumn{5}{|l|}{ Gender } \\
\hline Male & $\begin{array}{l}792 \\
(35.17)\end{array}$ & $\begin{array}{l}550 \\
(32.26)\end{array}$ & $193(44.16)$ & $\begin{array}{l}49 \\
(44.55)\end{array}$ \\
\hline Female & $\begin{array}{l}1460 \\
(64.83)\end{array}$ & $\begin{array}{l}1155 \\
(67.74)\end{array}$ & $244(55.84)$ & $\begin{array}{l}61 \\
(55.45)\end{array}$ \\
\hline \multicolumn{5}{|l|}{ Educational level } \\
\hline Less than high school & $\begin{array}{l}48 \\
(2.13)\end{array}$ & $\begin{array}{l}43 \\
(2.52)\end{array}$ & $2(0.64)$ & $3(2.73)$ \\
\hline High school & $\begin{array}{l}415 \\
(18.43)\end{array}$ & $\begin{array}{l}365 \\
(21.41)\end{array}$ & $34(7.78)$ & $\begin{array}{l}16 \\
(14.55)\end{array}$ \\
\hline Bachelor's degree & $\begin{array}{l}1416 \\
(62.88)\end{array}$ & $\begin{array}{l}1064 \\
(62.40)\end{array}$ & $274(62.70)$ & $\begin{array}{l}78 \\
(70.91)\end{array}$ \\
\hline Master's degree & $\begin{array}{l}214 \\
(9.50)\end{array}$ & $\begin{array}{l}147 \\
(8.62)\end{array}$ & 55 (12.59) & $\begin{array}{l}12 \\
(10.91)\end{array}$ \\
\hline Doctorate & $\begin{array}{l}159 \\
(7.06)\end{array}$ & $\begin{array}{l}86 \\
(5.04)\end{array}$ & 72 (16.48) & $1(0.91)$ \\
\hline \multicolumn{5}{|l|}{ Employment } \\
\hline Employed full-time & $\begin{array}{l}939 \\
(41.70)\end{array}$ & $\begin{array}{l}565 \\
(33.14)\end{array}$ & $279(63.84)$ & $\begin{array}{l}95 \\
(86.36)\end{array}$ \\
\hline Employed part-time & $\begin{array}{l}84 \\
(3.73)\end{array}$ & $\begin{array}{l}60 \\
(3.52)\end{array}$ & $16(3.66)$ & $8(7.27)$ \\
\hline
\end{tabular}

USD: United States dollar; COVID-19: Coronavirus disease 2019. 


\begin{tabular}{|c|c|c|c|c|}
\hline \multirow[t]{2}{*}{ Variable } & $\begin{array}{l}\text { Total } \\
\text { sample }\end{array}$ & Public & $\begin{array}{l}\text { Healthcare } \\
\text { workers }\end{array}$ & $\begin{array}{l}\text { Security } \\
\text { forces }\end{array}$ \\
\hline & $\mathbf{N}(\%)$ & $\mathbf{N}(\%)$ & $N(\%)$ & $N(\%)$ \\
\hline Unemployed & $\begin{array}{l}467 \\
(20.74)\end{array}$ & $\begin{array}{l}435 \\
(25.51)\end{array}$ & $32(7.32)$ & $0(0)$ \\
\hline Student & $\begin{array}{l}463 \\
(20.56)\end{array}$ & $\begin{array}{l}372 \\
(21.82)\end{array}$ & 88 (20.14) & $3(2.73)$ \\
\hline Retired & $\begin{array}{l}229 \\
(10.17)\end{array}$ & $\begin{array}{l}207 \\
(12.14)\end{array}$ & $19(4.35)$ & $3(2.73)$ \\
\hline Self-employed & $\begin{array}{l}70 \\
(3.11)\end{array}$ & $\begin{array}{l}66 \\
(3.87)\end{array}$ & $3(0.69)$ & $1(0.91)$ \\
\hline \multicolumn{5}{|l|}{ Marital status } \\
\hline Single & $\begin{array}{l}851 \\
(37.79)\end{array}$ & $\begin{array}{l}629 \\
(36.89)\end{array}$ & $192(43.94)$ & $\begin{array}{l}30 \\
(27.27)\end{array}$ \\
\hline Married & $\begin{array}{l}1281 \\
(56.88)\end{array}$ & $\begin{array}{l}983 \\
(57.65)\end{array}$ & $220(50.34)$ & $\begin{array}{l}78 \\
(70.91)\end{array}$ \\
\hline Divorced & $\begin{array}{l}95 \\
(4.22)\end{array}$ & $\begin{array}{l}72 \\
(4.22)\end{array}$ & $21(4.81)$ & $2(1.82)$ \\
\hline Widowed & $\begin{array}{l}25 \\
(1.11)\end{array}$ & $\begin{array}{l}21 \\
(1.23)\end{array}$ & $4(0.92)$ & $0(0)$ \\
\hline \multicolumn{5}{|l|}{ Income } \\
\hline ه1331 USD & $\begin{array}{l}885 \\
(39.30)\end{array}$ & $\begin{array}{l}754 \\
(44.22)\end{array}$ & $122(27.92)$ & $9(8.18)$ \\
\hline $1331-2662$ USD & $\begin{array}{l}504 \\
(22.38)\end{array}$ & $\begin{array}{l}355 \\
(20.82)\end{array}$ & $88(20.14)$ & $\begin{array}{l}61 \\
(55.45)\end{array}$ \\
\hline $2663-5325$ USD & $\begin{array}{l}582 \\
(25.84)\end{array}$ & $\begin{array}{l}440 \\
(25.81)\end{array}$ & $122(27.92)$ & $\begin{array}{l}20 \\
(18.18)\end{array}$ \\
\hline$₫ 5325$ USD & $\begin{array}{l}281 \\
(12.48)\end{array}$ & $\begin{array}{l}156 \\
(9.15)\end{array}$ & 105 (24.03) & $\begin{array}{l}20 \\
(18.18)\end{array}$ \\
\hline \multicolumn{5}{|l|}{ Location } \\
\hline Middle regions & $\begin{array}{l}363 \\
(16.12)\end{array}$ & $\begin{array}{l}258 \\
(15.13)\end{array}$ & 77 (17.62) & $\begin{array}{l}28 \\
(25.45)\end{array}$ \\
\hline Western regions & $\begin{array}{l}1451 \\
(64.43)\end{array}$ & $\begin{array}{l}1082 \\
(63.46)\end{array}$ & $308(70.48)$ & $\begin{array}{l}61 \\
(55.45)\end{array}$ \\
\hline Northern regions & $\begin{array}{l}111 \\
(4.93)\end{array}$ & $\begin{array}{l}89 \\
(5.22)\end{array}$ & $16(3.66)$ & $6(5.45)$ \\
\hline
\end{tabular}

USD: United States dollar; COVID-19: Coronavirus disease 2019. 


\begin{tabular}{|c|c|c|c|c|c|}
\hline \multirow{2}{*}{\multicolumn{2}{|c|}{ Variable }} & $\begin{array}{l}\text { Total } \\
\text { sample }\end{array}$ & Public & $\begin{array}{l}\text { Healthcare } \\
\text { workers }\end{array}$ & $\begin{array}{l}\text { Security } \\
\text { forces }\end{array}$ \\
\hline & & $N(\%)$ & $\mathbf{N}(\%)$ & $\mathbf{N}(\%)$ & $N(\%)$ \\
\hline \multicolumn{2}{|l|}{ Southern regions } & $\begin{array}{l}123 \\
(5.46)\end{array}$ & $\begin{array}{l}96 \\
(5.63)\end{array}$ & 17 (3.89) & $\begin{array}{l}10 \\
(9.09)\end{array}$ \\
\hline \multicolumn{2}{|l|}{ Eastern regions } & $\begin{array}{l}204 \\
(9.06)\end{array}$ & $\begin{array}{l}180 \\
(10.56)\end{array}$ & 19 (4.35) & $5(4.55)$ \\
\hline \multicolumn{6}{|l|}{ Nationality } \\
\hline \multicolumn{2}{|l|}{ Saudi } & $\begin{array}{l}2022 \\
(89.79)\end{array}$ & $\begin{array}{l}1542 \\
(90.44)\end{array}$ & 373 (85.35) & $\begin{array}{l}107 \\
(97.27)\end{array}$ \\
\hline \multicolumn{2}{|l|}{ Non-Saudi } & $\begin{array}{l}230 \\
(10.21)\end{array}$ & $\begin{array}{l}163 \\
(9.56)\end{array}$ & 64 (14.65) & $3(2.73)$ \\
\hline \multirow[t]{2}{*}{$\begin{array}{l}\text { Have you been diagnosed with Covid-19 } \\
\text { disease? }\end{array}$} & Yes & $\begin{array}{l}48 \\
(2.13)\end{array}$ & $\begin{array}{l}33 \\
(1.94)\end{array}$ & $9(2.06)$ & $6(5.45)$ \\
\hline & No & $\begin{array}{l}2204 \\
(97.87)\end{array}$ & $\begin{array}{l}1672 \\
(98.06)\end{array}$ & 428 (97.94) & $\begin{array}{l}104 \\
(94.55)\end{array}$ \\
\hline \multirow[t]{2}{*}{$\begin{array}{l}\text { Has anyone in your family been diagnosed } \\
\text { with Covid- } 19 \text { disease? }\end{array}$} & Yes & $\begin{array}{l}79 \\
(3.51)\end{array}$ & $\begin{array}{l}57 \\
(3.34)\end{array}$ & 17 (3.89) & $5(4.55)$ \\
\hline & No & $\begin{array}{l}2173 \\
(96.49)\end{array}$ & $\begin{array}{l}1648 \\
(96.66)\end{array}$ & $420(96.11)$ & $\begin{array}{l}105 \\
(95.45)\end{array}$ \\
\hline \multirow[t]{2}{*}{$\begin{array}{l}\text { Have you had contact with any Covid-19 } \\
\text { patients? }\end{array}$} & Yes & $\begin{array}{l}59 \\
(2.62)\end{array}$ & $\begin{array}{l}15 \\
(0.88)\end{array}$ & $44(10.07)$ & $0(0)$ \\
\hline & No & $\begin{array}{l}2193 \\
(97.38)\end{array}$ & $\begin{array}{l}1690 \\
(99.12)\end{array}$ & $393(89.93)$ & $\begin{array}{l}110 \\
(100)\end{array}$ \\
\hline
\end{tabular}

\section{Discussion}

This study reports the prevalence of psychological distress in the context of the COVID-19 pandemic and the strict curfew in the KSA. At the time of data collection, the number of COVID-19 cases was climbing exponentially and a nationwide, 24-hour curfew had been in effect for a full month. The literature contains much evidence that such circumstances during pandemics may result in a huge burden of psychological distress. In addition to fears of infection and other health-related fears, economic hardship resulting from restrictions on business and social activities may place a substantial burden on individuals and families (Cohn, 2010; Taylor, 2017). Inevitable differences in perceptions of the effects of authoritative action during pandemics may contribute to increased anxiety or even public unrest. The results from this study show that one-third to one-half of subjects experienced significant levels of psychological distress, with about $10 \%$ of the population reporting the most severe level of psychological 
distress. Some sociodemographic characteristics appeared to be risk factors for higher psychological distress in our sample. Healthcare workers seemed to experience a higher percentage of psychological distress than the public, a finding that is not surprising given previous study findings (Chew et al., 2020; Huang and Zhao, 2020; Lai et al., 2020; Lu et al., 2020; Tan et al., 2020; Zhang et al., 2020). Generally, younger and female subjects in our sample were more prone to psychological distress. This is similar to previous reports in the context of the COVID-19 pandemic (Lai et al., 2020; Liu et al., 2020; Qiu et al., 2020; Wang et al., 2020b). It is possible that the effects of sociocultural restrictions on daily life may be greater in young individuals than in older individuals. In addition, young people may be more likely to follow the news on social media outlets (Boczkowski et al., 2017). Consistent with our data, recent reports show that Chinese females have more symptoms of PTSD, depression, anxiety and stress during COVID pandemics (Lai et al., 2020; Liu et al., 2020; Qiu et al., 2020). Our results indicate that Master's graduates had significantly lower anxiety scores than Ph.D. graduates. Again, this is consistent with Chinese data collected during the COVID-19 pandemic (Qiu et al., 2020). A possible explanation is that educated people are more health aware and tend to be 'monitors' of their own health risks (Hahn and Truman, 2015). Contrary to our results, several studies have reported that low educational level is associated with greater psychological distress (Brooks et al., 2020; Cao et al., 2020; Moreira et al., 2020; Suryadevara et al., 2020). This may be because such individuals are 'blunters' of their health risks (i.e. they show avoidant behaviour), suggesting a U-shaped association between education and psychological distress during pandemics that requires further study.

The present data are in line with data from other countries in the context of the pandemic, and provide additional evidence of the mental health burden of the COVID-19 pandemic (Chaix et al., 2020; Chew et al., 2020; Filgueiras and Stults-Kolehmainen, 2020; Garcia-Priego et al., 2020; Jia et al., 2020; Jung et al., 2020; Moreira et al., 2020; Newby et al., 2020; Qiu et al., 2020; Rossi et al., 2020a; Rossi et al., 2020b; Sigdel et al., 2020; Suryadevara et al., 2020; Tan et al., 2020; Ueda et al., 2020; Vahedian-Azimi et al., 2020; Wang et al., 2020a). However (and even though we did not perform a comparative study between countries), there is no evidence from the local Saudi data that the strict curfews and restrictions have led to more severe psychological distress in the KSA than in other countries. The Iranian (Vahedian-Azimi et al., 2020) and Australian (Newby et al., 2020) populations showed higher DASS scores than the Saudi population. However, at the time of the Iranian and Australian data collections, there were restrictions on travel and mass gatherings and no strict complete curfews. Scores for Portuguese and Singapore samples were lower than our scores (Moreira et al., 2020; Newby et al., 2020; Tan et al., 2020; VahedianAzimi et al., 2020), even though the Portuguese study data collection (on 23 March) occurred 4 days after the Portuguese government had declared an emergency state and applied tight restrictions. In the Singapore study, Tan et al. acknowledged the limitations of conducting the study early in the outbreak, which may limit the generalizability of the findings (Tan et al., 2020). However, given the many sociocultural, health policy, political and demographic differences between these countries, firm conclusions about the effects of curfews and social restrictions cannot be drawn. Furthermore, the trends in COVID-19 cases and deaths are not homogeneous across countries. The KSA death rate has been one of the lowest in the world (Saudi Ministry of Health, 2020; World Health Organization, 2020). The low 
death rate may be partly related to the strict policies applied in the country and may have indirectly balanced the potential increase in psychological distress caused by these policies. Another factor that may have balanced out the potential increase in anxiety resulting from tight restrictions is that the curfews and restrictions reduced the chance of individuals coming into contact with COVID-19 cases. Our data show that history of contact with COVID-19 patients was associated with a higher risk of anxiety, which is consistent with previous data showing that the prospect of coming into contact with infected cases during a pandemic greatly increases anxiety during these periods (Mazza et al., 2020; Newby et al., 2020; Person et al., 2004; Qiu et al., 2020; Tan et al., 2020; Zandifar and Badrfam, 2020 .(

Risk communication with the public during pandemics plays a crucial role in shaping the psychological response during these difficult times, especially in countries where strict curfews are applied (Taylor, 2017). People are more likely to adhere to authority regulations if they believe that the authorities are being transparent and providing sufficient clear information. The government of Saudi Arabia held daily press briefings organized and conducted by the Ministry of Health. An application was launched and made available to all citizens. The application allowed people to access data and graphs on pandemic trends and to learn about the caseloads in the regions relevant to them (Saudi Ministry of Health, 2020). Different communication strategies were applied during this pandemic. A media campaign was launched to appeal to people's logical and emotional sides. The campaign portrayed adherence to health and curfew regulations as a patriotic act and a social responsibility that protects everybody. Evidence suggests that emotional approaches may have a stronger appeal than logical approaches (Betsch et al., 2011; Janssen et al., 2013; Taylor, 2017). Furthermore, the government instituted heavy fines on breaking curfews to discourage people from spreading the infection, which is another communication strategy that is helpful during pandemics (Taylor, 2017).

\section{Limitations}

This study has some limitations. First, this was not a comparative study with simultaneous prospective data collection from different countries; therefore, the data cannot be used to draw firm conclusions about the effect of curfew regulations on psychological burden during pandemics. Second, we used a convenience sample. This may have resulted in selection bias: individuals with very low or very high levels of anxiety may have refrained from participating in the study because they avoid accessing the news media on which the study tool was disseminated. Third, the design was sufficiently powerful to detect major differences in psychological distress scores, but may not have been sufficiently powerful to detect small differences between some subgroups (such as older adults, who constituted a relatively small proportion of our sample). Fourth, the sample was mostly drawn from the western region of the KSA, which may limit the generalizability of the findings to the rest of the country, let alone to other countries.

\section{Conclusions}


To the best of our knowledge, this is the first survey from the KSA to demonstrate the psychological impact of the COVID-19 pandemic. It supplements existing Chinese data on the psychological effects of strict curfews and social restrictions. We showed that there is indeed a psychological burden resulting from the pandemic in the KSA, but that this does not appear to differ from that of other countries with less strict regulations. These findings could inform health policy and further studies to identify appropriate responses to global pandemics. Our data suggest that strict curfews and policy regulations are not necessarily associated with a greater net psychological burden. However, further studies with purposeful sampling and pre-planned cross-country comparisons are needed.

\section{Declarations}

\section{Ethics approval and consent to participate:}

This study was approved by the research ethics committee of King Abdulaziz University (approval no. 234-20) and consent was obtained through agreement to participate in the survey from each person participating in the study.

Consent for publication: Not Applicable

Competing interests: The authors declare that they have no competing interests.

Funding: Not applicable

Authors' Contributions: BSA, YA, FSA and HOT designed the study, supervised the work and wrote the manuscript. HAT and AB collected the data. YA conducted the statistical analysis.

Acknowledgements: We thank Diane Williams, PhD, from Edanz Group (www.edanzediting.com/ac) for editing a draft of this manuscript.

\section{References}

Aday LA. Designing and conducting health surveys. 2nd ed. San Francisco: Jossey-Bass; 1996.

Alzahrani A, Alghamdi A, Alqarni T, Alshareef R, Alzahrani A. Prevalence and predictors of depression, anxiety, and stress symptoms among patients with type II diabetes attending primary healthcare centers in the western region of Saudi Arabia: a cross-sectional study. Int J Ment Health Syst. 2019;13:48.

Anderson RM, Heesterbeek H, Klinkenberg D, Hollingsworth TD. How will country-based mitigation measures influence the course of the COVID-19 epidemic? Lancet. 2020;395: 931-4.

Basudan S, Binanzan N, Alhassan A. Depression, anxiety and stress in dental students. Int J Med Educ. 2017;8:179-86. 
Beaufort IN, De Weert-Van Oene GH, Buwalda VAJ, de Leeuw JRJ, Goudriaan AE. The Depression, Anxiety and Stress Scale (DASS-21) as a screener for depression in substance use disorder inpatients: a pilot study. European Addiction Research. 2017;23:260-8.

Betsch C, Ulshöfer C, Renkewitz F, Betsch T. The influence of narrative v. statistical information on perceiving vaccination risks. Medical Decision Making. 2011;31:742-53.

Boczkowski P, Mitchelstein E, Matassi M. Incidental news: how young people consume news on social media. 2017.

Brooks SK, Webster RK, Smith LE, Woodland L, Wessely S, Greenberg N, et al. The psychological impact of quarantine and how to reduce it: rapid review of the evidence. Lancet. 2020;395:912-20.

Cao W, Fang Z, Hou G, Han M, Xu X, Dong J, et al. The psychological impact of the COVID-19 epidemic on college students in China. Psychiatry Research. 2020;287:112934.

Chaix B, Delamon G, Guillemasse A, Brouard B, Bibault JE. Psychological distress during the COVID-19 pandemic in France: a national assessment of at-risk populations. Preprint at https://www.medrxiv.org/content/10.1101/2020.05.10.20093161v2 (2020).

Chew NWS, Lee GKH, Tan BYQ, Jing M, Goh Y, Ngiam NJH, et al. A multinational, multicentre study on the psychological outcomes and associated physical symptoms amongst healthcare workers during COVID19 outbreak. Brain, Behavior, and Immunity. 2020; doi:10.1016/j.bbi.2020.04.049

Cohn SK. Cultures of plague: medical thinking at the end of the Renaissance. Oxford: Oxford University Press; 2010.

Cullen W, Gulati G, Kelly BD. Mental health in the COVID-19 pandemic. QJM. 2020;113: 311-2.

Ebrahim SH, Ahmed QA, Gozzer E, Schlagenhauf P, Memish ZA. Covid-19 and community mitigation strategies in a pandemic. BMJ. 2020;368:m1066.

Filgueiras A, Stults-Kolehmainen M. Factors linked to changes in mental health outcomes among Brazilians in quarantine due to COVID-19. medRxiv. 2020.2005.2012.20099374.

Garcia-Priego BA, Triana-Romero A, Pinto-Galvez SM, Duran-Ramos C, Salas-Nolasco O, Manriquez Reyes $M$, et al. Anxiety, depression, attitudes, and internet addiction during the initial phase of the 2019 coronavirus disease (COVID-19) epidemic: a cross-sectional study in Mexico. medRxiv. 2020.2010.20095844.

Hahn RA, Truman BI. Education improves public health and promotes health equity. Int J Health Serv. 2015;45:657-78. 
Hall RC, Hall RC, Chapman MJ. The 1995 Kikwit Ebola outbreak: lessons hospitals and physicians can apply to future viral epidemics. General Hospital Psychiatry. 2008;30:446-52.

Henry JD, Crawford JR. The short-form version of the Depression Anxiety Stress Scales (DASS-21): construct validity and normative data in a large non-clinical sample. British Journal of Clinical Psychology. 2005;44:227-39.

Holmes EA, O'Connor RC, Perry VH, Tracey I, Wessely S, Arseneault L, et al. Multidisciplinary research priorities for the COVID-19 pandemic: a call for action for mental health science. Lancet Psychiatry. 2020;7:P547-60.

Huang Y, Zhao N. Mental health burden for the public affected by the COVID-19 outbreak in China: who will be the high-risk group? Psychology, Health \& Medicine. 2020;1-12.

Janssen $E$, van Osch L, de Vries $H$, Lechner L. Examining direct and indirect pathways to health behaviour: the influence of cognitive and affective probability beliefs. Psychology \& Health. 2013;28:54660 .

Jia R, Ayling K, Chalder T, Massey A, Broadbent E, Coupland C, et al. Mental health in the UK during the COVID-19 pandemic: early observations. medRxiv. 2020.2005.2014.20102012.

Jung S, Kneer J, Krueger T. The German COVID-19 Survey on Mental Health: primary results. medRxiv. 2020.2005.2006.20090340.

Kulsoom B, Afsar NA. Stress, anxiety, and depression among medical students in a multiethnic setting. Neuropsychiatr Dis Treat. 2015;11:1713-22.

Lai J, Ma S, Wang Y, Cai Z, Hu J, Wei N, et al. Factors associated with mental health outcomes among health care workers exposed to coronavirus disease 2019. JAMA. 2020;3: e203976.

Liu N, Zhang F, Wei C, Jia Y, Shang Z, Sun L, et al. Prevalence and predictors of PTSS during COVID-19 outbreak in China hardest-hit areas: gender differences matter. Psychiatry Research. 2020;287:112921.

Lovibond PF. Long-term stability of depression, anxiety, and stress syndromes. Journal of Abnormal Psychology. 1998;107:520-6.

Lovibond SH, Lovibond PF. Manual for the Depression Anxiety Stress Scales. Sydney: Psychology Foundation of Australia; 1996.

Lovibond SH, Lovibond PF. Manual for the Depression Anxiety Stress Scales. 2nd ed. Sydney: Psychology Foundation of Australia; 2004.

Lu W, Wang H, Lin Y, Li L. Psychological status of medical workforce during the COVID-19 pandemic: a cross-sectional study. Psychiatry Research. 2020;288:112936. 
Mazza C, Ricci E, Biondi S, Colasanti M, Ferracuti S, Napoli C, et al. A nationwide survey of psychological distress among Italian people during the COVID-19 pandemic: immediate psychological responses and associated factors. International Journal of Environmental Research and Public Health. 2020;17.

Moreira PS, Ferreira S, Couto B, Machado-Sousa M, Fernandez M, Raposo-Lima C, et al. Protective elements of mental health status during the COVID-19 outbreak in the Portuguese population. medRxiv. 2020.2004.2028.20080671.

Newby J, O'Moore K, Tang S, Christensen H, Faasse K. Acute mental health responses during the COVID19 pandemic in Australia. medRxiv. 2020.2005.2003.20089961.

Norton PJ. Depression Anxiety and Stress Scales (DASS-21): psychometric analysis across four racial groups. Anxiety, Stress, and Coping. 2007;20:253-65.

Ou X, Liu Y, Lei X, Li P, Mi D, Ren L, et al. Characterization of spike glycoprotein of SARS-CoV-2 on virus entry and its immune cross-reactivity with SARS-CoV. Nature Communications. 2020;11:1620.

Perrin PC, McCabe OL, Everly GS Jr, Links JM. Preparing for an influenza pandemic: mental health considerations. Prehospital and Disaster Medicine. 2009;24:223-30.

Person B, Sy F, Holton K, Govert B, Liang A. Fear and stigma: the epidemic within the SARS outbreak. Emerging Infectious Diseases. 2004;10:358-63.

Pfefferbaum B, North CS. Mental health and the Covid-19 pandemic. New England Journal of Medicine. 2020.

Qiu J, Shen B, Zhao M, Wang Z, Xie B, Xu Y. A nationwide survey of psychological distress among Chinese people in the COVID-19 epidemic: implications and policy recommendations. General Psychiatry. 2020;33:e100213.

Rossi R, Socci V, Pacitti F, Di Lorenzo G, Di Marco A, Siracusano A, et al. Mental health outcomes among front and second line health workers associated with the COVID-19 pandemic in Italy. medRxiv. 2020a.2004.2016.20067801.

Rossi R, Socci V, Talevi D, Mensi S, Niolu C, Pacitti F, et al. COVID-19 pandemic and lockdown measures impact on mental health among the general population in Italy. An N=18147 web-based survey. medRxiv, 2020b.2004.2009.20057802.

Rubin GJ, Potts HW, Michie S. The impact of communications about swine flu (influenza A H1N1v) on public responses to the outbreak: results from 36 national telephone surveys in the UK. Health Technology Assessment. 2010;14:183-266.

Saudi Ministry of Health. 2020. COVID 19 Dashboard: Saudi Arabia. 
Sigdel A, Bista A, Bhattarai N, Poon BC, Giri G, Marqusee H, et al. Depression, anxiety and depressionanxiety comorbidity amid COVID-19 pandemic: an online survey conducted during lockdown in Nepal. medRxiv. 2020.2004.2030.20086926.

Suryadevara V, Adusumalli C, Adusumilli PK, Chalasani SH, Radhakrishnan R. Mental health status among the south Indian pharmacy students during Covid-19 pandemic quarantine period: a crosssectional study. medRxiv. 2020.2005.2008.20093708.

Tan BYQ, Chew NWS, Lee GKH, Jing M, Goh Y, Yeo LLL, et al. Psychological impact of the COVID-19 pandemic on health care workers in Singapore. Annals of Internal Medicine. 2020.

Taylor S. The psychology of pandemics: preparing for the next global outbreak of infectious disease. UK: Cambridge Scholars; 2017.

Tran TD, Tran T, Fisher J. Validation of the depression anxiety stress scales (DASS) 21 as a screening instrument for depression and anxiety in a rural community-based cohort of northern Vietnamese women. BMC Psychiatry. 2013;13:24.

Ueda M, Stickley A, Sueki H, Matsubayashi T. Mental health status of the general population during the COVID-19 pandemic: a cross-sectional national survey in Japan. medRxiv. 2020.2004.2028.20082453.

Vahedian-Azimi A, Moayed MS, Rahimibashar F, Shojaei S, Ashtari S, Pourhoseingholi MA. Compare the severity of psychological distress among four groups of Iranian society in COVID-19 pandemic. Research Square. 2020.

Van Bortel T, Basnayake A, Wurie F, Jambai M, Koroma AS, Muana AT, et al. Psychosocial effects of an Ebola outbreak at individual, community and international levels. Bulletin of the World Health Organization. 2016;94:210-4.

Wang C, Pan R, Wan X, Tan Y, Xu L, Ho CS, et al. Immediate psychological responses and associated factors during the initial stage of the 2019 Coronavirus disease (COVID-19) epidemic among the general population in China. International Journal of Environmental Research and Public Health. 2020a;17.

Wang C, Pan R, Wan X, Tan Y, Xu L, Mclntyre RS, et al. A longitudinal study on the mental health of general population during the COVID-19 epidemic in China. Brain, Behavior, and Immunity. 2020b.

World Health Organization. 2020. Coronavirus disease (COVID-19) dashboard.

Zaki AM, van Boheemen S, Bestebroer TM, Osterhaus AD, Fouchier RA. Isolation of a novel coronavirus from a man with pneumonia in Saudi Arabia. New England Journal of Medicine. 2012;367:1814-20.

Zandifar A, Badrfam R. Iranian mental health during the COVID-19 epidemic. Asian Journal of Psychiatry. 2020;51:101990. 
Zhang MW, Ho C, Fang P, Lu Y, Ho RC. Usage of social media and smartphone application in assessment of physical and psychological well-being of individuals in times of a major air pollution crisis. JMIR mHealth and uHealth. 2014;2:e16.

Zhang W, Wang K, Yin L, Zhao W, Xue Q, Peng M, et al. Mental health and psychosocial problems of medical health workers during the COVID-19 epidemic in China. Psychother Psychosom. 2020.

\section{Figures}

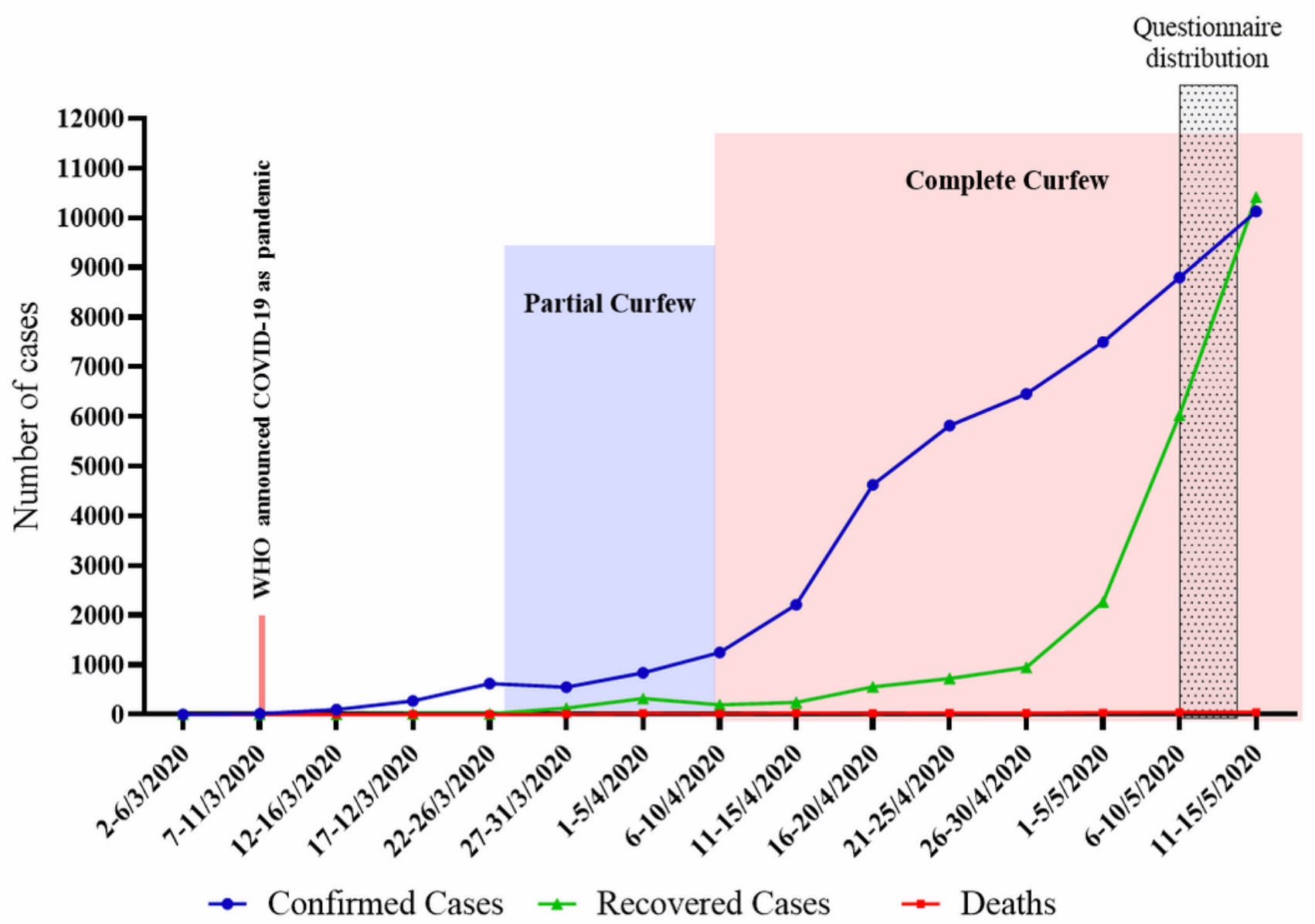

\section{Figure 1}

Number of COVID-19 cases in KSA: 2 March (first confirmed case) to 15 May 2020. https://covid19.cdc.gov.sa/ar/daily-updates-ar/ 


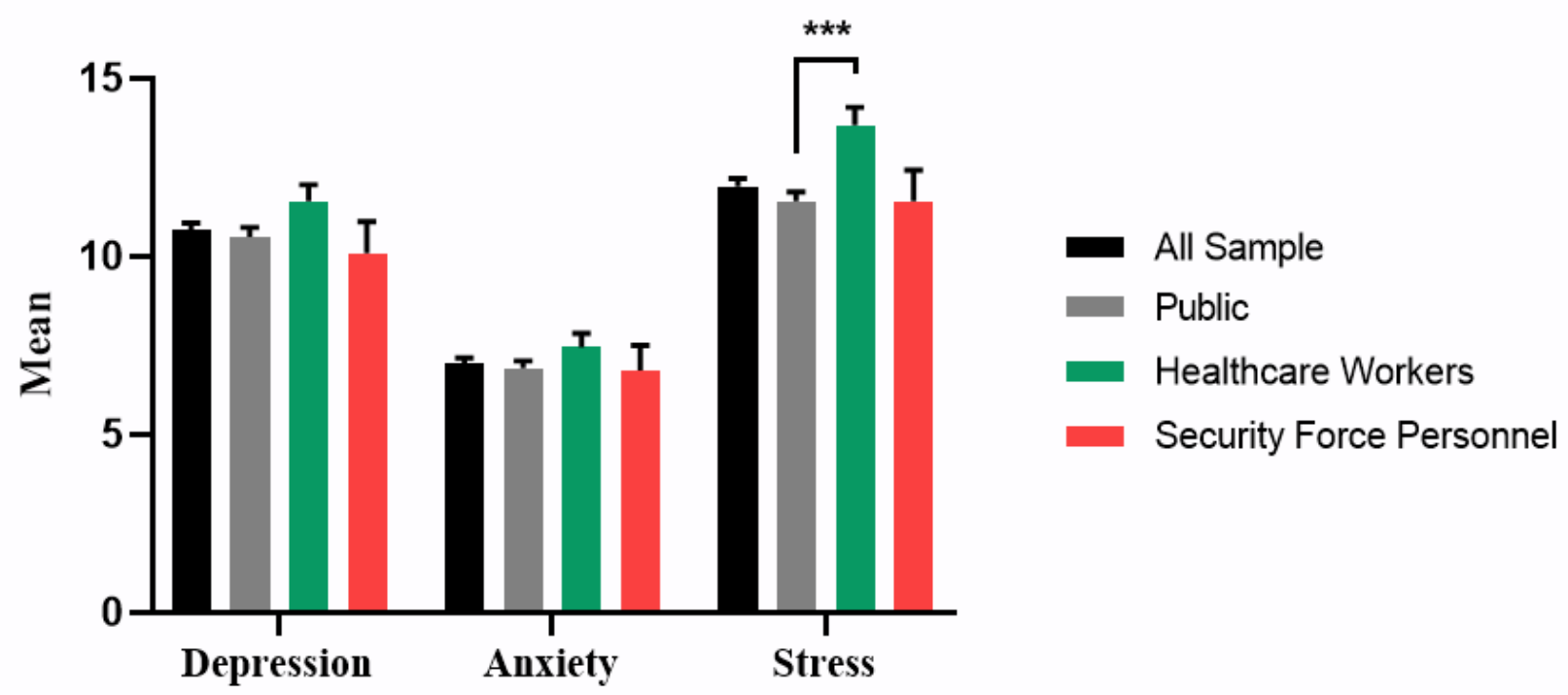

Figure 2

Mean depression, anxiety and stress scores: total sample, public, healthcare workers and security force personnel. 


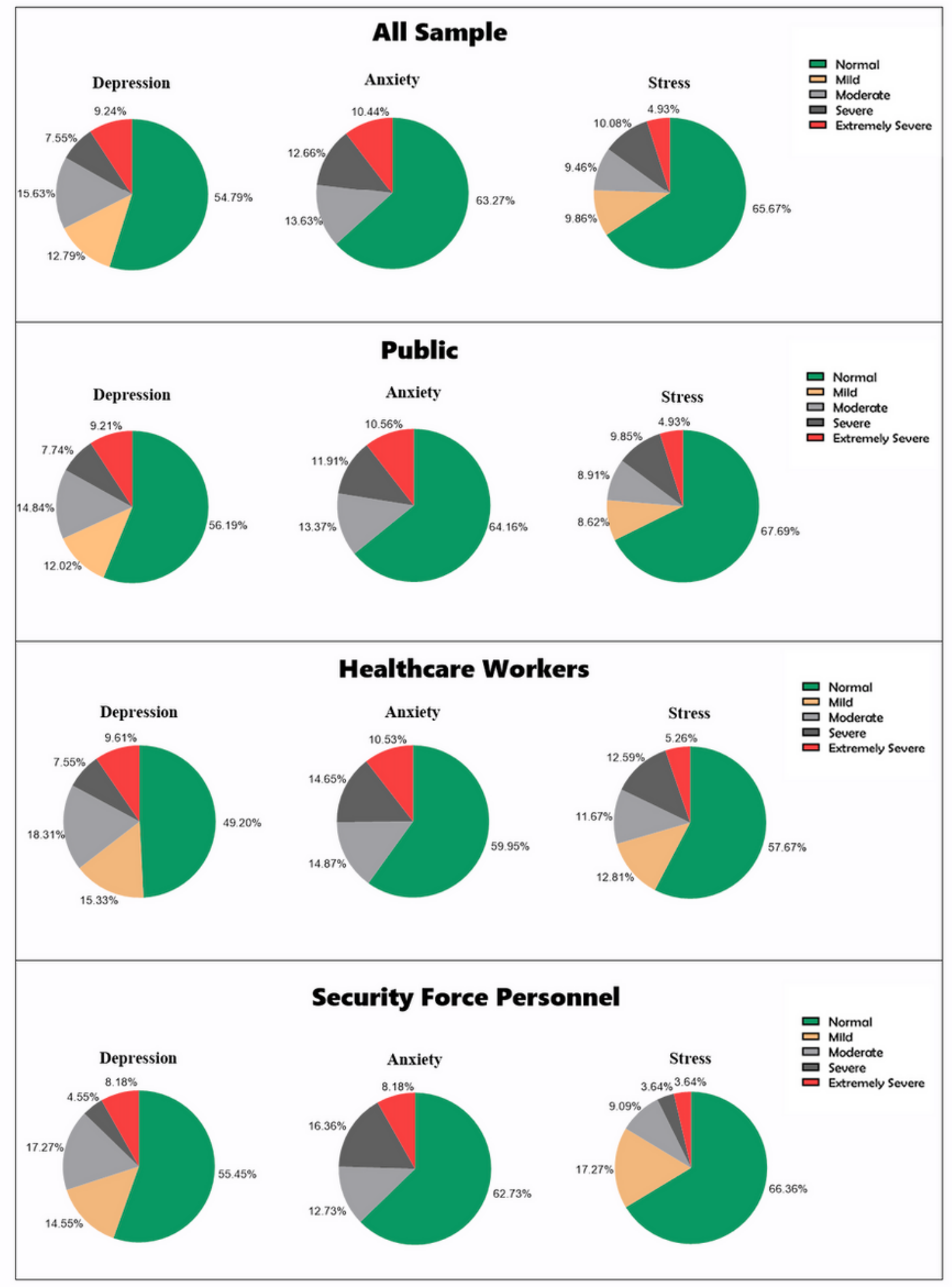

Figure 3

Proportion of participants with different levels of each psychological disorder: total sample. 
Depreession

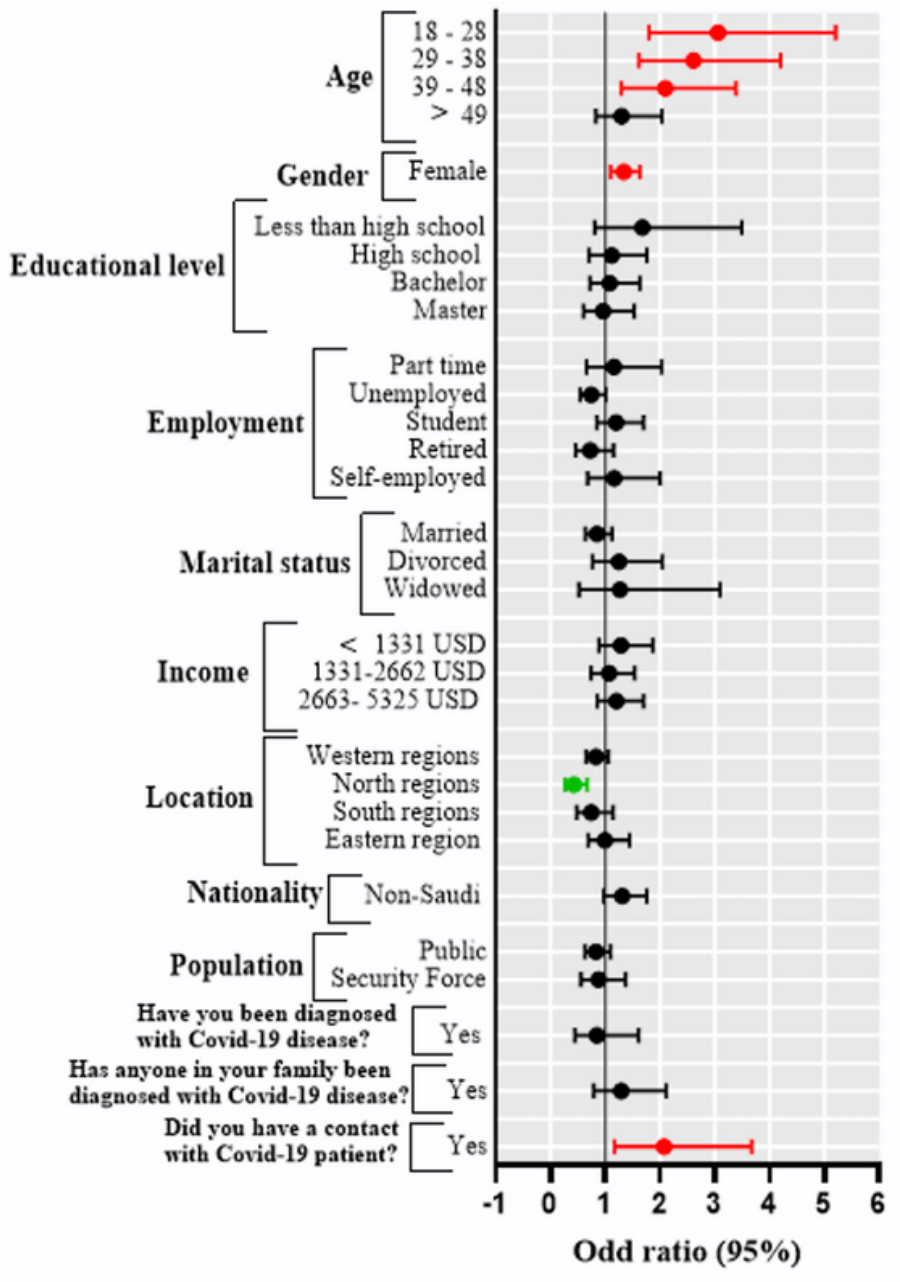

Anxiety

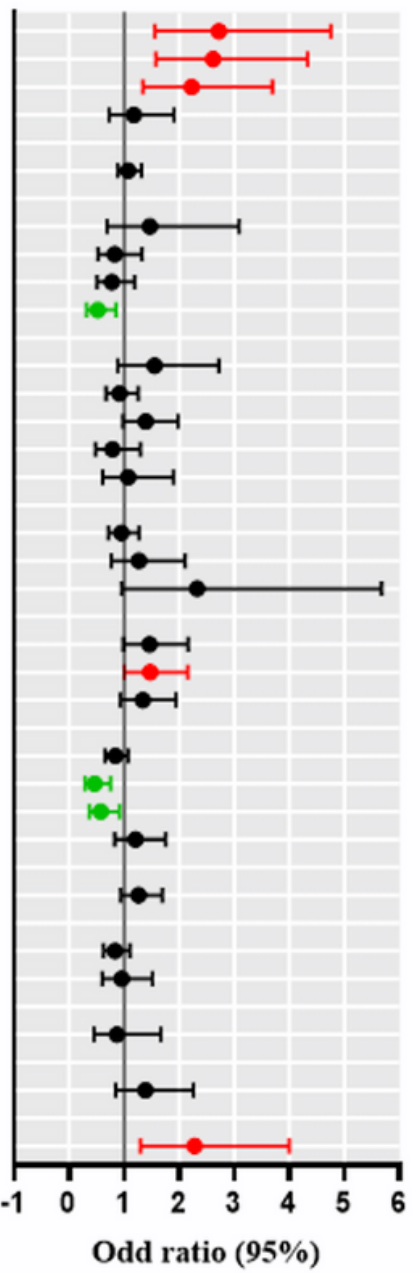

Stress

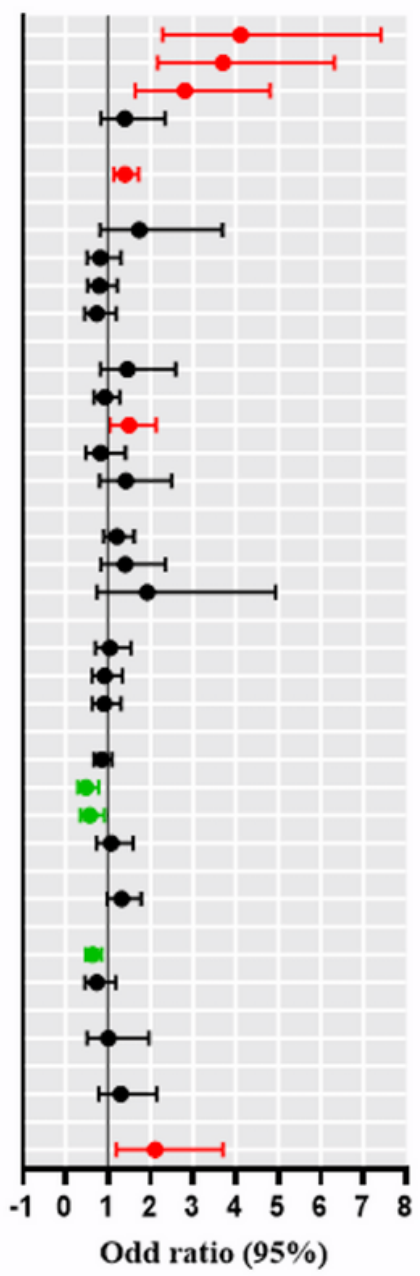

\section{Figure 4}

Forest plot of odds ratios and $95 \%$ confidence intervals $(\mathrm{Cl})$. Each panel represents the correlation between predictors and specific psychological parameters (depression, anxiety, stress). Each row represents a specific predictor with the corresponding odds ratio (dot) and 95\% $\mathrm{Cl}$ (horizontal line). The red horizontal line indicates a positive correlation; the green horizontal line indicates a negative correlation.

\section{Supplementary Files}

This is a list of supplementary files associated with this preprint. Click to download.

- SupplementaryTable.docx 